\title{
Limpograss and hymenachne grown on flatwoods range pond margins
}

\author{
ROB KALMBACHER, JEFF MULLAHEY, AND KEVIN HILL
}

Authors are professor, Range Cattle Research and Education Center, Ona, Fla 33865 and assoc. professor, Southwest Florida Research and Education Center, Immokalee, Fla. 34143, and extension agent II, Naples, Fla. 33964. University of Florida Journal Series No. R-05498.

\section{Abstract}

Limpograss (Hemarthria altissima [Poir] Stapf and C.E. Hubb) and hymenachne (Hymenachne amplexicaulis [Rudge] Nees) may reduce weight loss of cows graxing Florida range from September to March. These grasses were grown on maidencane (Panicum hemitomon Schult) pond margins and were evaluated as stockpiled forage (ungrazed 6-10 months) at 2 locations over 4 years. Floralta limpograss received 0 or $3,000 \mathrm{~kg}$ dolomite ha (2 whole plots) and N-P-K fertilizer (5 subplots): 50-25-50, 50-25-0, 50-0-50, 50-0-0, 0-0-0 kg/ha. Hymenachne was grown without dolomite, $N, P$, or $K$. Hymenachne failed to establish at Ona in central Florida, but persisted for 1 year at Immokalee near the Everglades where dry matter production in October to January was $1,540,2,160$, and $2,910 \mathrm{~kg} / \mathrm{ha}$ at 35,70 , and 105 days after $N$ fertilization, respectively. Crude protein $(56 \mathrm{~g} / \mathrm{kg})$ was highest at 70 days and IVOMD $(47.4 \%)$ was highest at 105 days. Limpograss established without dolomite, $N, P$, or $K$ fertilization, and forage available for winter grazing often exceeded 7,000 $\mathrm{kg} / \mathrm{ha}$. Application of $50 \mathrm{~kg} \mathrm{~N} / \mathrm{ha}$ to stockpiled limpograss increased yield (compared to no $N$ ) in 1 of 4 years at Ona and in both years at Immokalee. Applying $\mathbf{N}$ to stockpiled limpograss always increased crude protein and IVOMD above that of grass receiving no $\mathrm{N}$, but increases were slight $(10 \mathrm{~g}$ crude protein $/ \mathrm{kg})$. Crude protein seldom exceeded $50 \mathrm{~g} / \mathrm{kg}$ with $50 \mathrm{~kg}$ N/ha applied in late August at Ona or in Octoher at Immokalee. In vitro organic matter digestion often exceeded $45 \%$, which could help limit weight loss of cows grazing range in winter. Neither grass was observed to be invasive, as growth was confined to plots after 5 and 8 years at Immokalee and Ona, respectively.

Key Words: Hemarthria altissima, Hymenachne amplexicaulis, supplementation, fertilization

Cows grazing range year-round in Florida typically calve in alternate years because excessive weight loss in winter and failure of cows to regain weight in spring limits rebreeding (Hughes 1974). Rotation burning of range and feeding molasses-based supplements helps reduce winter weight loss, but these practices are often not enough (Kalmbacher et al. 1995). Just as pasture in spring helps cows regain weight lost in winter (Lewis and McCormick 1971), selected introduced grasses used as nutrient banks may reduce cow weight loss from September to March when cows graze range.

Manuscript received 23 Dec. 1996
Resumen

EI pasto limpo (Hemarthria altissima [Poir] Stapf and C.E. Hubb) y paja de agua (Hymenachne amplexicaulis (Rudge Nees) puede reducir la perdida de peso de las vacas pastando praderas nativas en la Florida de Septiembre a Marzo. Estos pastos crecieron en las margenes de las lagunas o pantanos donde estaba establecido maidencane (Panicum hemitomon Schult) y fueron evaluados como heno en pie (sin pastorear 6-10 meses) en dos localidades por mas de 4 años. El pasto limpo recibio 0 o 3.000 kg dolomita/ha (2 parcelas completas) y se fertilizo con N-P-K (5 subparcelas ): 50-25-50, 50-50-0, 50-0-50, 50-0-0, 0-0-0 kg/ha. Paja de agua crecio sin dolomita, N, P, o K. Paja de agua no crecio en Ona, localizada en la parte central de la Florida, pero persistió por 1 año en Immokalee cerca de los Everglades donde la producción de materia seca de Octubre a Enero fue de 1.540, 2.160, y $2.910 \mathrm{~kg} / \mathrm{ha}$ en 35,70, y 105 días después de ser fertilizada con $N$. La proteina cruda $(56 \mathrm{~g} / \mathrm{kg})$ fue mas alta a los 70 días y DMOIV (47\%) fue mas alta a los 105 días. El pasto limpo se establecio sin fertilización con dolomita, $N, P, K$ y el forraje disponible para el pastoreo en invierno a menudo excedio 7,000 $\mathrm{kg} / \mathrm{ha}$. La aplicación de $50 \mathrm{~kg} \mathrm{~N} / \mathrm{ha}$ al pasto limpo como heno en pie incrementó el rendimiento (al compararlo $\sin N$ ) en 1 de los 4 años en Ona y en ambos años en Immokalee. Aplicando $\mathbf{N}$ al pasto limpo como heno en pie siempre incremento la proteína cruda y DMOIV por encima de los pastos que no recibieron $\mathbf{N}$, pero los incrementos fueron ligeros $(10 \mathrm{~g}$ proteína cruda/ $\mathrm{kg})$. La proteína cruda raras veces excedio $50 \mathrm{~g} / \mathrm{kg}$ para $50 \mathrm{~kg} / \mathrm{N} / \mathrm{ha}$ aplicado a finales de Agosto en Ona o en Octubre en Immokalee. La digestion de materia organica in vitro a menudo excedio el $45 \%$, lo cual podria ayudar a limitar la perdida de peso en las vacas pastando durante el invierno. Ningun pasto observado fue invasivo, su crecimiento de mantuvo en parcelas durante 5 y 8 años en Immokalee y Ona, respectivamente.

Throughout the acid, infertile upland flatwoods are shallow depressions known as maidencane (Panicum hemitomon Schult.) ponds. Between flatwoods and ponds are transitional areas that are usually brush-free, have relatively fertile soils, and could be planted easily to adapted forages (Fig. 1). There are 2 grasscs with potential.

Limpograss (Hemarthria altissima [Poir] Stapf and C.E. Hubb) was introduced into Florida in 1964, and the cultivar Floralta is now widely grown on pasture with poorly drained soil (Quesenberry et al. 1984). It maintains a level of digestibility with maturity that is well above that of other mature tropical 


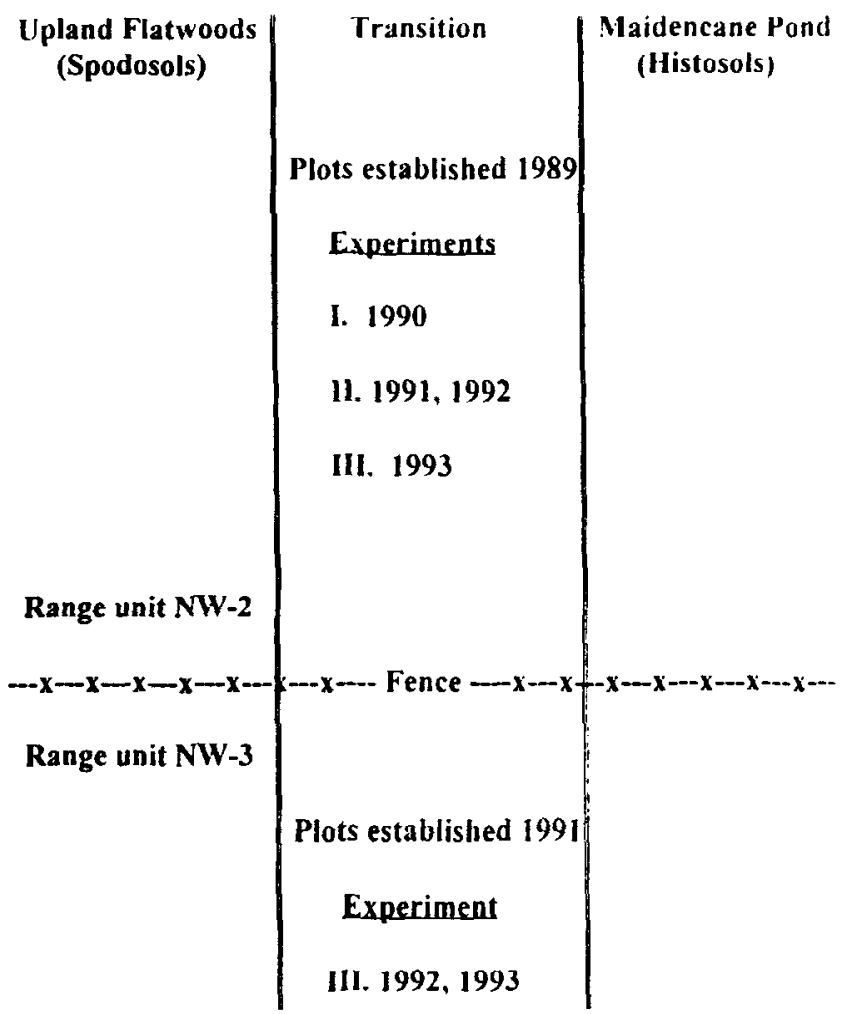

Fig. 1. Lay-out for Experiments I-IV at the Range Cattle Research and Education Center illustrating the concept of nutrition banks for cows grazing Florida range in winter.

grasses (Schank et al. 1973), which makes it ideal for stockpiling. In plot studies simulating pasture, limpograss was staged in early August and fertilized with $64 \mathrm{~kg} \mathrm{~N} / \mathrm{ha}$, and it yielded 4,500 and $8,000 \mathrm{~kg}$ dry matter (DM)/ha at 60 and 90 days after fertilization, respectively, with 64 and $58 \%$ invitro organic matter digestion (IVOMD), respectively (Quesenberry and Ocumpaugh 1980).

Hymenachne amplexicaulis ([Rudge] Nees) (no common name), a native of the West Indies, is used in ponded pastures in Australia (Wildin and Chapman 1988). It has not been planted in Florida for pasture, but can be found in the Everglades area in freshwater ponds characterized by standing water (up to $3 \mathrm{~m}$ ) for at least 9 months. Hymenachne is productive $(3,000$ to $20,000 \mathrm{~kg}$ $\mathrm{DM} / \mathrm{ha}$ ) (Tejos 1980, Dirven 1962) and has relatively high crude protein ( 90 to $230 \mathrm{~g} / \mathrm{kg}$ ) (Dirven 1962).

On range, these grasses would not be grazed from March to early September because cow-calf pairs are moved from range to pasture until September when calves are weaned. Research on stockpiled limpograss has focused on time of deferral and $\mathrm{N}$ fertilization after its use during the growing season and before the stockpiling period (Davis et al. 1987, Kretschmer and Snyder 1979, Quesenberry and Ocumpaugh 1980, Ruelke and Quesenberry 1983). Managing these grasses on range would require improvement of nutritive value after stockpiling.

The purpose of this research was to determine: (1) if limpograss and hymenachne could be grown on pond margins with little or no dolomite, $\mathrm{P}$, or $\mathrm{K}$ fertilizer beyond establishment, and (2) if $\mathrm{N}$ fertilizer increased yield and nutritive value of stockpiled grass. At the Range Cattle Research and Education Center (REC), this later aspect was expanded to include time of $\mathrm{N}$ fertilization.

\section{Materials and Methods}

Four experiments were conducted at the Range Cattle REC in central Florida between 1989 and 1993 (Fig. 1 and Table 1), and 1 experiment was conducted at the Immokalee Ranch near the Everglades between 1991 and 1993.

\section{Range Cattle REC}

Soil was a transition between a Pomona fine sand (sandy, siliceous, hyperthermic Ultic, Alaquod) and a Floridana mucky fine sand (loamy, siliceous, hyperthermic Arenic Argiaquoll). The experimental design was 4 replications of a split plot of 2 dolomite treatments $(0$ and $3,000 \mathrm{~kg} / \mathrm{ha})$, which formed whole plots, and 5 fertilizer treatments, which formed subplots arranged as randomized, complete blocks within dolomite treatments. Each whole plot was $6 \times 15 \mathrm{~m}$, and subplots were $6 \times 3 \mathrm{~m}$. Only $6 \times$ $1.5 \mathrm{~m}$ was fertilized in each subplot, leaving a $6-X 3-\mathrm{m}$ unfertilized border between each subplot. Fertilizer treatments $(\mathrm{kg} / \mathrm{ha}$ of N-P-K) for limpograss were: (1) 50-25-50, (2) 50-0-0, (3) 50-250 , (4) 50-0-50, and (5) 0-0-0 (check). Phosphorus and $\mathrm{K}$ fertilizers were applied by hand once at limpograss planting. Nitrogen fertilizer was applied once annually, and the timing of $\mathrm{N}$ fertilization in relation to date of sampling established a series of experiments (Table 1). Ammonium nitrate, triple superphosphate, and muriate of potash was used to supply $\mathrm{N}, \mathrm{P}$, and $\mathrm{K}$, respectively. Micronutrients were not applied. Hymenachne plots consisted of 4 replications of no dolomite, no fertilizer.

Table 1. Four experiments were conducted at the Range Cattle REC between 1990 and 1993. Experiments differed as to date when $50 \mathrm{~kg} / \mathrm{ha}$ $\mathrm{N}$ fertilizer was applied (A) and limpograss was sampled (S).

\begin{tabular}{|c|c|c|c|c|c|c|c|c|c|c|}
\hline & Year & $\overline{\mathrm{J}}$ & $\mathrm{J}$ & A & 5 & 0 & $\mathrm{~N}$ & $\mathrm{D}$ & Unit & Days A-S \\
\hline I & $1990^{1}$ & A & & & $S$ & & & & NW-2 & 105 \\
\hline II & $1991^{2}$ & & & & A & & & $\mathbf{S}$ & NW-2 & 63 \\
\hline \multirow[t]{2}{*}{ III } & $1992^{3}$ & & & $\mathbf{A}$ & & $S$ & $S$ & $\mathbf{S}$ & NW-3 & $35,78,105$ \\
\hline & $1992^{4}$ & & & & & A & $\mathrm{S}$ & $\mathbf{S}$ & NW-2 & 35,68 \\
\hline \multirow[t]{2}{*}{ IV } & $1993^{5}$ & & & A & $\mathrm{S}$ & & & & NW-2 & 30 \\
\hline & $1993^{6}$ & & & & & & A & $\mathbf{S}$ & NW-3 & 30 \\
\hline
\end{tabular}

${ }^{1}$ Fertilized 30 June and sampled 19 Sept.

${ }^{2}$ Fertilized 30 Sept. and sampled 2 Dec.

${ }^{3}$ Fertilized 31 Aug. and sampled 5 Oct., 17 Nov., and 14 Dec.

Fertilized 15 Oct. and sampled 19 Nov. and $22 \mathrm{Dec}$.

${ }^{5}$ Fertilized 31 Aug. and sampled 29 Sept.

6 Fertilized 15 Nov. and sampled 15 Dec.

Two sites were planted to Floralta limpograss (Fig 1.): NW-2 (August 1989) and NW-3 (August 1991) which were in adjacent range units grazed beginning in October or December through February. Both sites were disked twice on the day before planting and dolomite was applied by hand at $3,000 \mathrm{~kg} / \mathrm{ha}$. Plots were disked to incorporate dolomite and then to incorporate about $2,000 \mathrm{~kg} / \mathrm{ha}$ (fresh weight) of vegetative planting material. Planted areas were rolled to firm the seedbed. Hymenachne was planted vegetatively in August and replanted November 1991 in NW-3 using the same procedures as those for limpograss but without dolomite.

Grass was clipped at ground level in a $1-\mathrm{m}^{2}$ quadrat in each plot. Forage was dried 96 hours at $60^{\circ} \mathrm{C}$ for dry matter determination. When sampled over time after $\mathrm{N}$ fertilization, the quadrat was placed on areas not previously clipped. On the day of sam- 
pling in 1990, 1991 and 1992 (35-day sample only), native plant species present in 7 to $10,1-\mathrm{m}^{2}$ quadrats in the adjacent transition area (no dolomite, no fertilizer) were recorded and clipped. Grasses and grasslikes were combined, while forbs were clipped as a separate group. About $100 \mathrm{~g}$ of dried forage was ground and analyzed for crude protein (Gallaher et al. 1975, Hambleton 1977) and IVOMD (Moore and Mott 1974).

Soil in each NW-2 plot was sampled (0-15 cm) in March 1990, October 1991, and August 1993 and in February 1992 and December 1993 in NW-3. Soil was analyzed for $\mathrm{pH}, \mathrm{Ca}, \mathrm{Mg}, \mathrm{P}$, and $\mathrm{K}$ (Mehlich I extractable [0.05 $\mathrm{M} \mathrm{HCl}$ and $\left.0.01 M \mathrm{H}_{2} \mathrm{SO}_{4}\right]$ ) at the Analytical Research Laboratory at the University of Florida (Hanlon and Devore 1989).

Cows grazed surrounding range and limpograss plots from the date they were last sampled until February when cows were moved to pasture to begin their breeding season. Limpograss was always completely utilized by February and did not require staging.Limpograss was allowed to grow all summer without grazing.

\section{Immokalee Ranch}

The Immokalee Ranch, which borders the Everglades, is much wetter than the Range Cattle REC. Soil was a transition between a Boca fine sand (loamy, siliceous, hyperthermic Arenic Ochraqualf) and a Winder (fine-loamy, siliceous, hyperthermic Typic Glossaqualf), Chobee (fine-loamy, siliceous, hyperthermic Typic Argiaquoll), and a Gator (loamy, siliceous, euic, hyperthermic Terric Medisaprist). Floralta limpograss and hymenachne were planted in November 1991. The experimental design, treatments, and fertilizer materials for limpograss were the same as those at the Range Cattle REC.

Phosphorous and $\mathrm{K}$ fertilizers were applied annually in April 1992 and 1993, and $\mathrm{N}$ fertilizer was applied annually in October. Plots were sampled by clipping grass to ground level in a different $1-\mathrm{m}^{2}$ quadrat within each plot at 35,70 , and 105 days after $\mathrm{N}$ fertilization. At each harvest in both years, native plant species growing in a $0.5-\mathrm{m}^{2}$ quadrat in 4 plots, which had no planted grass, no dolomite, and no fertilizer were recorded and clipped (grasses and grassilikes together, forbs separately). Forage samples were dried, ground, and analyzed for nutritive value as listed above. Soil was sampled in each plot $(0-15 \mathrm{~cm})$ before treatment in November 1991 and December 1993 and analyzed the same as soil from the Range Cattle REC. Cows were excluded from the experimental arca from April to January but were allowed to graze the surrounding area throughout the year. Limpograss and hymenachne were allowed to grow all summer without grazing.

\section{Data Analyses}

Data were analyzed by a generalized linear model (SAS 1985). Effects due to year or sample date within year were determined with repeated measures option. Significant $(P<0.05)$ fertilizer treatment effects were investigated with Duncan's Multiple Range test at the Range Cattle REC and the Waller-Duncan test at the Immokalee Ranch.

\section{Results and Discussion}

\section{Rainfall}

Range Cattle REC. Total annual rainfall in 1989 to 1993 was $1,052,1,133,1,619,1,203$, and 1,262 $\mathrm{mm}$ compared to a 54-year mean of $1,683 \mathrm{~mm}$. In spite of lower than average rainfall in each year, there were typical periods of saturated soil during each June to September wet season. Plots were occasionally covered with 2$3 \mathrm{~cm}$ of water for up to 7 days.

Immokalee Ranch. Rainfall for 1992 and 1993 totaled 1,197 and $1,381 \mathrm{~mm}$ at the Southwest REC, which is located about 9.6 $\mathrm{km}$ north of the Immokalee Ranch. Water covered the plots as late as mid October 1993.

\section{Soil pH and Minerals}

Range Cattle REC. Soil $\mathrm{pH}$ and concentrations of $\mathrm{Ca}$ and $\mathrm{Mg}$ were greater in plots where $3,000 \mathrm{~kg} / \mathrm{ha}$ dolomite had been applied to NW-2 and NW-3 (Table 2). Soil pH and concentrations of these minerals in soil did not change over years. The increase in $\mathrm{pH}$ and concentrations of $\mathrm{Ca}$ and $\mathrm{Mg}$ as a result of dolomite application were similar to increases in $\mathrm{pH}$ and $\mathrm{Ca}$ and $\mathrm{Mg}$ concentrations observed after addition of $3,000 \mathrm{~kg} / \mathrm{ha}$ of dolomite to an unlimed Pomona fine sand (Rechcigl et. al 1993). Concentrations of $\mathrm{P}$ and $\mathrm{K}$ were not affected by dolomite or fertilizer treatments or sample dates and averaged 3 and $11 \mathrm{mg} / \mathrm{kg}$, respectively.

Table 2. Soil pH, Ca, and $\mathrm{Mg}$ (mg/kg) in NW-2 and NW-3 at the Range Cattle REC and Immokalee Ranch.

\begin{tabular}{|c|c|c|c|c|}
\hline & Dolomite & $\mathrm{NW}-2^{1}$ & NW-3 $3^{2}$ & Immokalee \\
\hline & (kg/la) & & & \\
\hline \multirow[t]{3}{*}{$\mathrm{pH}$} & 0 & 4.8 & 4.8 & 5.0 \\
\hline & 3,000 & 5.9 & 5.8 & 5.3 \\
\hline & & $* *$ & $* *$ & ns \\
\hline \multirow[t]{3}{*}{$\mathrm{Ca}$} & 0 & 174 & 159 & 466 \\
\hline & 3,000 & 364 & 365 & 574 \\
\hline & & $* *$ & $* *$ & $* *$ \\
\hline \multirow[t]{3}{*}{$\mathrm{Mg}$} & 0 & 46 & 38 & 36 \\
\hline & 3,000 & 113 & 100 & 40 \\
\hline & & $* *$ & $* *$ & $* *$ \\
\hline
\end{tabular}

Averaged over samples taken 9 Mar. 1990, 1 Oct. 1991, and 30 Aug. 1993.

${ }^{2}$ Averaged over samples taken $7 \mathrm{Feb} .1992$ and $28 \mathrm{Dec} .1993$.

${ }^{3}$ Sample taken December 1993, 2 years after dolomite application.

** F-test for dolomite treatment significant $(P=0.01)$

Immokalee Ranch. In 1993, soil pH was not affected by dolomite, but concentrations of $\mathrm{Ca}$ and $\mathrm{Mg}$ were greater where $3,000 \mathrm{~kg} / \mathrm{ha}$ dolomite had been applied in 1991 (Table 2). Soils in this region are underlaid with calcareous material, giving the soils a higher $\mathrm{pH}$ than suils at the Range Cattle REC. Concentrations of $P(25 \mathrm{mg} / \mathrm{kg})$ and $K(35 \mathrm{mg} / \mathrm{kg})$ were not affected by dolomite or fertilizer treatments, but both were greater than $\mathbf{P}$ and $\mathrm{K}$ concentrations in the soil at the Range Cattle REC.

\section{Native Forages}

Range Cattle REC. Grasses included (most to least) broomsedge (Andropogon virginicus L), chalky bluestem ( $A$. capillipes Nash), giant carpetgrass (Axonopus furcatus [Flugge] Hitchc.), low panicums (Dichanthelium spp.), sour paspalum (Paspalum conjugatum Berg.), and maidencane. Grasslikes were sedges (Carex spp.), rushes (Rhynchospora spp.), razor sedge (Scleria reticularis Michx.), and rush fuirena (Fuirena scirpoidea Michx.). Yield of grasses and grasslikes in the unfertilized, native transition area in NW-2 averaged 2,230 kg DM/ha over 1990 to 1993. In NW-3, native grasses yielded $780 \mathrm{~kg} / \mathrm{ha} 1992$. Forbs were Solidago fistulosa Ait. (no common name), Mohr's eupatorium (Eupatorium mohrii Greene), flat-topped goldenrod (Euthamia minor [Michx.] Greene), and meadow beauty (Rhexia 
nutatalli James). Their yield averaged $450 \mathrm{~kg} / \mathrm{ha}$ in NW-2 and $630 \mathrm{~kg} / \mathrm{ha}$ in NW-3. Crude protein for grasses and grasslikes (combined) and forbs both averaged $44 \mathrm{~g} / \mathrm{kg}$, and their IVOMD averaged $33.9 \%$ and $31.8 \%$, respectively.

Immokalee Ranch. Grasses included little carpetgrass (Axonopus affinis Chase), broomsedge, maidencane, and Paspalum spp. Grasslikes included Carex spp. and Scleria spp. Forbs included Solidago, Eupatorium, Hydrocotyl spp, and Hypericum spp. Dry matter yield of native grasses and forbs averaged 360 and $88 \mathrm{~kg} / \mathrm{ha}$, respectively, over both years.

A transition area similar to the ones at the Range Cattle REC and Immokalee Ranch yielded $1,890 \mathrm{~kg}$ DM/ha of grasses and $840 \mathrm{~kg} / \mathrm{ha}$ of forbs at the start of grazing in January (Kalmbacher et al. 1984). Diets of steers grazing this transition area from December to February contained an average $70 \mathrm{~g}$ crude protein $/ \mathrm{kg}$ and $34.0 \%$ IVOMD (Long et al. 1986).

\section{Hymenachne}

Range Cattle REC. Both attempts to establish hymenachne failed at the Range Cattle REC. Hymenachne requires alternating periods of flooding and dryness for optimum growth, seed production, and persistence (Wildin 1988). Periods of flooding occurred at the Range Cattle REC, but pond margins typically became very dry in April and May before the rainy season, which may have been a problem because hymenachne is not drought tolerant (Medina and Motta 1990). Soil pH, and P, K, and Ca concentrations were low at the Range Cattle REC compared to Immokalee Ranch (Table 2). We planted hymenachne in 3 other ponds around the Range Cattle REC, including the muck in the center of a maidencane pond. After 5 years, hymenachne had spread little from the area in the 1 pond where it survived.

Immokalee Ranch. Yield of hymenachne was 1,540 (November), 2,160 (December), and 2,910 (January) kg/ha at 35, 70 , and 105 days, respectively, after stockpiling began in October. Hymenachne persisted for 1 year on the sandy pond margin, but hymenachne planted on muck for observational purposes in the center of the pond in 15 to $30 \mathrm{~cm}$ water still persisted after 3 years. Crude protein concentration in hymenachne was highest for the 70-day harvest $(56 \mathrm{~g} / \mathrm{kg})$, followed by the $35-(45$ $\mathrm{g} / \mathrm{kg}$ ) and the 105-day ( $37 \mathrm{~g} / \mathrm{kg}$ ) harvests. Values for IVOMD were highest for the 105 -day $(47.4 \%)$ followed by the $35-(46.5 \%)$ and 70 -day (43.9\%) harvests. In an earlier study, hymenachne grown on the muck in the centcr of a pond was 52.1, 51.9, and $50.3 \%$ IVOMD when cut on 30-, 60-, and 90-day intervals, respectively (unpublished data, K.U. Hill). Yields during summer in Hill's study ranged from 6,000 to $14,900 \mathrm{~kg} \mathrm{DM} / \mathrm{ha}$ at 30 -to 90-day clipping intervals, respectively.

\section{Limpograss}

Range Cattle REC, Experiment 1. There were no differences in limpograss yields (average $6,800 \mathrm{~kg} / \mathrm{ha}$ ) due to dolomite or fertilizer treatments. The large mass of limpograss present at $\mathrm{N}$ fertilization in June (not measured), time between $\mathrm{N}$ fertilization and sampling (105 days), and probable leaching of $N$ during the June to September rainy season were considered responsible for lack of treatment differences.

Limpograss is noted for its ability to accumulate large amounts of dry matter with little or no $\mathrm{N}$ fertilizer. With no $\mathrm{N}$, limpograss produced 5,950 and $10,490 \mathrm{~kg} /$ ha with 63 and 126 days growth, respectively (Christiansen 1982 as cited by Quesenberry et al.
1984). Limpograss fertilized with $75 \mathrm{~kg} / \mathrm{ha}$ of $\mathrm{N}$ produced 10,500 $\mathrm{kg}$ DM/ha over a 130-day period (Ruelke and Quesenberry 1983).

No information on the effect of $P$ and $K$ fertilization on limpograss establishment was found. Established limpograss in a plot study was found to increase in yield with $K$ fertilization with maximum yield at $37 \mathrm{~kg} \mathrm{~K} / \mathrm{ha}$ after each harvest (Snyder and Kretschmer 1986). Under grazing conditions, there was no difference in total annual yield of limpograss receiving $\mathrm{P}$ ( 0 or 30 $\mathrm{kg} / \mathrm{ha}$ ) or K (0 or $56 \mathrm{~kg} / \mathrm{ha}$ ) alone or in combination (Rechcigl and Kalmbacher, unpublished data).

Crude protein $(20 \mathrm{~g} / \mathrm{kg})$ and IVOMD $(46.9 \%)$ were not affected by dolomite or fertilizer treatments in Experiment I. Our values were similar to crude protein $(30 \mathrm{~g} / \mathrm{kg}$ ) in limpograss fertilized with $75 \mathrm{~kg}$ of N/ha 120 days before sampling (Ruelke and Quesenberry 1983) and in vitro dry matter digestion IVDMD $(47 \%)$ in limpograss fertilized with $67-7-26 \mathrm{~kg} / \mathrm{ha}$ of $\mathrm{N}-\mathrm{P}-\mathrm{K}$, respectively, about 120 days before sampling (Davis et al. 1987).

Range Cattle REC, Experiment II. On 2 December, 63 days after $\mathbf{N}$ fertilization, there were no differences in yield due to dolomite or fertilizer treatments (average $11,850 \mathrm{~kg} / \mathrm{ha}$ ). Crude protein and IVOMD were not affected by dolomite, $\mathrm{P}$, or $\mathrm{K}$. Treatments containing $\mathrm{N}$ fertilizer were not different among themselves and averaged $25 \mathrm{~g}$ crude protein $/ \mathrm{kg}$ and $47.2 \%$ IVOMD. Treatments with $\mathrm{N}$ fertilizer were higher in crude protein and IVOMD than the check, which was $15 \mathrm{~g}$ crude protein $/ \mathrm{kg}$ and $43.7 \%$ IVOMD.

Range Cattle REC, Experiment III. There was no effect due to dolomite, but fertilizer treatments affected limpograss yield, crude protein, and IVOMD (no interaction with sample dates) (Table 3). With application of $\mathrm{N}$ in August on NW-3, N+P, N+ $K$, and $N+P+K$ treatments were not different from each other in yield, but were greater than $\mathrm{N}+\mathrm{O}+0$ and the check. On NW3 , limpograss yield declined linearly over sample dates $(13,200$, 11,900 , and $10,370 \mathrm{~kg} / \mathrm{ha}$ at $35,78,105$ days, respectively). With application of $\mathrm{N}$ in October on $\mathrm{NW}-2, \mathrm{~N}+\mathrm{P}$ and $\mathrm{N}+\mathrm{P}+\mathrm{K}$ treatments resulted in greater yield than $N+K$ and the check with the $\mathrm{N}+\mathbf{0}+0$ treatment intermediate. On NW-2, there was no difference in yield between sample dates (average $11,150 \mathrm{~kg} / \mathrm{ha}$ ).

Crude protein and IVOMD were greater in treatments containing $\mathbf{N}$ compared to the check, with little or no difference due to fertilizer P or K (Table 3). In NW-3, effect of sample date was significant with average crude protein concentrations of 22,16 , and $18 \mathrm{~g} / \mathrm{kg}$ and IVOMD $49.5,42.9$, and $42.8 \%$ at 35,78 , and 105 days after August fertilization, respectively. Both crude pro-

Table 3. Dry matter yield, crude protein, and IVOMD in limpograss forage that accumulated from March to October with annual application of $\mathbf{N}$ fertilizer in August (NW-3) or Octoher (NW-2). Values are means over 35,78 , and 105 days after fertilization with $N$ in $N W-3$ and 35 and 68 days in NW-2. Experiment II, Range Cattle REC.

\begin{tabular}{|c|c|c|c|c|c|c|c|c|}
\hline \multirow[b]{2}{*}{$\mathbf{N}$} & \multirow[b]{2}{*}{$\mathbf{P}^{1}$} & \multirow[b]{2}{*}{$\mathbf{K}^{1}$} & \multicolumn{2}{|c|}{ Yield } & \multicolumn{2}{|c|}{ Crude protein } & \multicolumn{2}{|c|}{ IVOMD } \\
\hline & & & NW-3 & NW-2 & NW-3 & NW-2 & NW-3 & NW-2 \\
\hline & & & \multicolumn{2}{|c|}{$\ldots \ldots(\mathrm{kg} / \mathrm{ha}) \ldots$} & \multicolumn{2}{|c|}{$\ldots(\mathrm{g} / \mathrm{kg}) \ldots$} & \multicolumn{2}{|c|}{$\ldots-(\%)-\ldots$} \\
\hline 50 & 25 & 50 & $13,000 \mathrm{a}^{2}$ & $12,290 \mathrm{a}$ & $20 \mathrm{ab}$ & $22 \mathrm{a}$ & $45.5 \mathrm{a}$ & $44.3 \mathrm{a}$ \\
\hline 50 & 25 & 0 & $12,820 \mathrm{a}$ & $12,280 \mathrm{a}$ & $20 \mathrm{ab}$ & $21 \mathrm{a}$ & $45.7 \mathrm{a}$ & $45.8 \mathrm{a}$ \\
\hline 50 & 0 & 50 & $12,500 \mathrm{a}$ & 10,2906 & $17 b$ & $18 \mathrm{ab}$ & $45.5 \mathrm{a}$ & $45.2 \mathrm{a}$ \\
\hline 50 & 0 & 0 & $11,020 \mathrm{~b}$ & $11,630 \mathrm{ab}$ & $23 \mathrm{a}$ & $23 a$ & $45.5 \mathrm{a}$ & $45.6 \mathrm{a}$ \\
\hline 0 & 0 & 0 & $9,900 \mathrm{~b}$ & $9,230 \mathrm{c}$ & $12 \mathrm{~b}$ & $13 b$ & $43.1 \mathrm{~b}$ & $41.4 \mathrm{~b}$ \\
\hline
\end{tabular}

${ }_{\mathrm{P}}$ and $\mathrm{K}$ were applied once at grass establishment.

${ }^{2}$ Means within columns followed by the same letter are not different (Duncan's multiple range test $\mathrm{P}<0.05$ ). 
tein and IVOMD declined between 35 and 78 days, but did not decline further at 105 days. Crude protein in limpograss declined from $80 \mathrm{~g} / \mathrm{kg}$ at 35 days after August fertilization (67 kg of N/ha) to $30 \mathrm{~g} / \mathrm{kg}$ at 112 days after fertilization (Ruelke and Quesenberry 1983). In NW-2, the effect of sample date was not significant for nutritive value with average (35 and 68 days after fertilization) crude protein at $21 \mathrm{~g} / \mathrm{kg}$ and IVOMD at $44.4 \%$.

Range Cattle REC, Experiment IV. Dolomite had no effect on yield, crude protein, or IVOMD. There were no differences in yield due to fertilizer treatments with $\mathrm{N}$ applied in August (NW-2 yielded $7,750 \mathrm{~kg} / \mathrm{ha}$ ) or November 1993 (NW-3 yielded 12,200 $\mathrm{kg} / \mathrm{ha}$ ). Application of $50 \mathrm{~kg}$ of N/ha increased yield (compared to no $\mathrm{N}$ ) in 1 out of 4 experiments at the Range Cattle REC. When limpograss is allowed to grow all summer, the maximum amount of grass that the site can produce may have accumulated by the date that $N$ is applied.Ruelke and Quesenberry (1983) and Quesenberry and Ocumpaugh (1980) found that limpograss reached a yield plateau $(9,000 \mathrm{~kg} / \mathrm{ha})$ where DM losses equaled gains. Applying $\mathrm{N}$ to mature pangolagrass (Digitaria decumbens Stent.) in December did not increase yields, but did raise crude protein concentration when grass was sampled 28 days later (Kretschmer 1965). August application of $\mathrm{N}$ fertilizer to grass that had been cut, followed by 56 to 70 days regrowth was recommended for limpograss stockpiled for fall-winter pasture in north Florida (Quesenberry and Ocumpaugh 1980, Ruelke and Quesenberry 1983).

On both Experiment IV sites, there were no differences in crude protein among treatments receiving $\mathrm{N}$ (average $27 \mathrm{~g} / \mathrm{kg}$ ), but these treatments resulted in greater limpograss crude protein than the check (average $16 \mathrm{~g} / \mathrm{kg}$ ). There were no differences in IVOMD among treatments receiving $\mathrm{N}$ (average $41.3 \%$ ), but limpograss from these treatments had greater IVOMD than the check (average $37.5 \%$ ). In 3 of 4 experiments at the Range Cattle REC, applying $\mathrm{N}$ to stockpiled grass from August to December increased crude protein and IVOMD above no $\mathrm{N}$ fertilization. Since stockpiled limpograss is extremely low in crude protein and the increases due to $\mathrm{N}$ fertilization were seldom more than $10 \mathrm{~g}$ crude protein $/ \mathrm{kg}$, it may not amount to a practical improvement; however, our laboratory estimates of nutritive value were based on whole plant samples, not grazed forage.

Immokalee Ranch. Dolomite had no affect on limpograss yield, crude protein, or IVOMD in either year. Year, fertilizer treatment, and sample date interacted for yield (Table 4). Generally, yield increased as clipping interval increased, especially when $\mathrm{N}$ was applied, and even more when $\mathrm{P}$ or $\mathrm{P}+\mathrm{K}$ was applied. Unlike the Range Cattle REC, where yield declined over Experiment III sample dates, yield of $\mathrm{N}$ fertilized limpograss increased over 1992 sample dates at the Immokalee Ranch. Limpograss growth continued longer into the winter at the Immokalee Ranch, which is about $135 \mathrm{~km}$ south of the Range Cattle REC. In 1993, the change in yield over sample dates depended on treatment, with the check and $50+0+50$ declining in yield with other treatments not changing.

Year, fertilizer treatment, and sample date interacted for crude protein and IVOMD (Table 4). Generally, nutritive value improved with application of $\mathrm{N}$ (compared to no $\mathrm{N}$ ) and more so when $P$ or $P+K$ was applied. This was especially apparent in 1993. Unlike Experiment III at the Range Cattle REC where nutritive value declined over sample dates, there was no clear cut pattern in nutritive value among treatments over sample dates at Immokalee Ranch. Both crude protein and IVOMD in the $N+P$
Table 4. Effect of fertilization on dry matter yield, crude protein, and in vitro organic matter digestion (IVOMD) of limpograss forage that accumulated on a pond margin at the Immokalee Ranch from April to October.

\begin{tabular}{|c|c|c|c|c|c|c|c|c|}
\hline \multirow[b]{3}{*}{$\mathbf{N}$} & \multicolumn{8}{|c|}{ Days following $\mathrm{N}$ fertilizer application in October } \\
\hline & \multirow[b]{2}{*}{$\mathbf{P}^{\mathbf{I}}$} & \multirow[b]{2}{*}{$\mathbf{K}^{\mathbf{l}}$} & 35 & 70 & 105 & 35 & 70 & 105 \\
\hline & & & \multicolumn{2}{|c|}{$\ldots$} & - & \multicolumn{3}{|c|}{$\ldots \ldots+\ldots 93 \ldots$} \\
\hline & & \multicolumn{7}{|c|}{$\ldots \ldots \ldots \ldots$ (yield, $\mathrm{kg} / \mathrm{ha}) \ldots \ldots \ldots$} \\
\hline 50 & 25 & 0 & $5.270 \mathrm{a}^{2}$ & $7,120 \mathrm{a}$ & $7.510 \mathrm{a}$ & $5,490 \mathrm{ab}$ & $5,700 \mathrm{~b}$ & $5,780 \mathrm{a}$ \\
\hline 50 & 25 & 50 & $4,910 \mathrm{a}$ & $7,280 a$ & $7,720 \mathrm{a}$ & $6,550 \mathrm{a}$ & $7,420 \mathrm{a}$ & $6,840 \mathrm{a}$ \\
\hline 50 & 0 & $\mathbf{0}$ & $3,350 \mathrm{a}$ & $5,210 \mathrm{ab}$ & $4,950 b$ & $4,170 \mathrm{~b}$ & $3,180 d$ & $3,910 \mathrm{~b}$ \\
\hline 50 & 0 & 50 & $3,340 \mathrm{i}$ & $3,760 \mathrm{~b}$ & $5,410 \mathrm{~b}$ & $5,140 b$ & $4,060 \mathrm{~cd}$ & $3,880 \mathrm{~b}$ \\
\hline \multirow[t]{2}{*}{0} & 0 & 0 & $3,620 \mathrm{a}$ & $3,690 \mathrm{~b}$ & $4,070 b$ & $4,620 \mathrm{~b}$ & $5,380 b c$ & $2,650 c$ \\
\hline & & & \multicolumn{6}{|c|}{$\ldots \ldots \ldots$ (crude protein, g/kg) $\ldots \ldots \ldots$} \\
\hline 50 & 25 & 0 & $46 \mathrm{abc}$ & $43 a$ & $46 a$ & $45 a$ & $40 \mathrm{a}$ & $45 \mathrm{ab}$ \\
\hline 50 & 25 & 50 & 48ab & $44 a$ & $42 a$ & $47 a$ & $42 a$ & $44 a b$ \\
\hline 50 & 0 & 0 & $53 a$ & $45 a$ & $47 \mathrm{a}$ & $46 a$ & $45 a$ & $49 a$ \\
\hline 50 & 0 & 50 & $33 b c$ & $42 a$ & $37 a$ & $33 b$ & $28 b$ & $38 b c$ \\
\hline \multirow[t]{2}{*}{0} & 0 & 0 & $32 c$ & $45 a$ & $37 a$ & $31 b$ & $31 b$ & $35 c$ \\
\hline & & & \multicolumn{6}{|c|}{$\ldots($ IVOMD, \%) } \\
\hline 50 & 25 & 0 & $44.7 \mathrm{a}$ & $44.5 a$ & $45.0 \mathrm{a}$ & $48.3 a$ & $44.9 \mathrm{a}$ & $45.0 \mathrm{a}$ \\
\hline 50 & 25 & 50 & $45.5 a$ & $42.8 \mathrm{a}$ & $42.8 \mathrm{ab}$ & $46.8 \mathrm{ab}$ & $45.4 a$ & $42.8 \mathrm{a}$ \\
\hline 50 & 0 & 0 & $44.5 a$ & $45.3 \mathrm{a}$ & $41.8 \mathrm{a}$ & $44.7 \mathrm{bc}$ & $44.7 \mathrm{a}$ & $41.8 \mathrm{a}$ \\
\hline 50 & 0 & 50 & $38.6 \mathrm{~b}$ & $44.6 \mathrm{a}$ & $39.8 \mathrm{~b}$ & $42.8 \mathrm{c}$ & $41.2 b$ & $39.8 \mathrm{a}$ \\
\hline 0 & 0 & 0 & $39.5 b$ & $43.1 \mathrm{a}$ & $41.1 b$ & $42.9 \mathrm{c}$ & $42.5 b$ & $41.1 \mathrm{a}$ \\
\hline
\end{tabular}

${ }_{\mathrm{P}}$ and $\mathrm{K}$ were applied annually in April.

${ }^{2}$ Means within columns followed by the same letter are not different (Waller-Duncan multiple range test, $\mathrm{P}<0.05$ ).

$+\mathrm{K}$ treatment declined over dates in both years, while nutritive value of other treatments varied but remained about the same over dates. The check treatment increased in crude protein over sample dates in both years.

\section{Invasive Grasses}

After 5 years at the Immokalee Ranch and 8 years at the Range Cattle REC, limpograss was confined to plots and had not spread. Limpograss must be vegetatively propagated and essentially produces no seed. Hymenachne was not found on pond margins where it was planted or elsewhere at the Range Cattle REC. Hymenachne, which produces seed, has been spreading on organic soils which remain flooded for long periods in the Everglades area. Further north, it may not be an invasive grass outside of stream channels.

\section{Summary and Application}

Hymenachne was not adapted to soil at the Range Cattle REC and lasted only 1 year on a pond margin at the Immokalee Ranch. Fertilizer N, P, K, and dolomite were not needed for establishment of limpograss on pond margins at either location. Nitrogen may increase yield of limpograss that has been stockpiled for 6 to 8 months, but this increase was consistent only at Immokalee Ranch. Application of $\mathrm{N}$ fertilizer consistently improved crude protein and IVOM at both locations. At the Immokalee Ranch, $\mathbf{P}$ and $\mathrm{K}$ increased yield in both years. Application of $\mathrm{P}$ or $\mathrm{K}$ had no effect on crude protein or IVOMD at either location.

In central and south Florida, maidencane ponds generally vary from 2 to $4 \mathrm{ha}$, and they constitute about 15\% of the range. A 2 ha pond with a $15 \mathrm{~m}$ border planted to limpograss provides about 0.8 ha of limpograss, which could produce about $8,000 \mathrm{~kg}$ 
DM/ha. A section of range with 40 ha of ponds whose margins (16 ha) were planted to limpograss, could produce about 128,000 $\mathrm{kg}$. Native vegetation on transition areas in a section of range would produce about $43,000 \mathrm{~kg}$. Planting pond margins to limpograss can provide a well distributed supply of economical, relatively digestible forage for winter grazing. Limpograss is low in crude protein regardless of $\mathrm{N}$ fertilization, and cows will require protein supplementation.

\section{Literature Cited}

Davis, C.E., V.D., Jolley, G.D. Mooso, L.R. Robison, and R.D. Horrocks. 1987. Quality of stockpiled bigalta limpograss forage at varying fertility levels. Agron. J. 79:229-235.

Dirven, J.G.P. 1962. De voederwaarde van bladeren en stengels bij tropische grassen. Surin. Landb. No. 5, pp.199-202.

Gallaher, R.N., C.O. Weldon, and J.G. Futral. 1975. An aluminum block digester for plant and soil analysis. Soil Sci. Soc. Amer. Proc. 89:803-806.

Hanlon, E.A. and J.M. DeVore. 1989. IFAS extension soil testing laboratory procedures and training manual. Fla. Agr. Exp. Sta., Cir. 812.

Hambleton, L.G. 1977. Semiautomated method for simultaneous determination of phosphorous, calcium and crude protein in animal feeds. J. Assoc. Off. Anal. Chem. 60:846-852.

Hughes, R.H. 1974. Management and utilization of pineland threeawn range in south Florida. J. Range Manage. 27:186-192.

Kalmbacher, R.S., W.F. Brown, and F.M. Pate. 1995. Effect of molasses-based liquid supplements on digestibility of creeping bluestem and performance of brood cows wintered on range. J. Anim. Sci. 73:853-860.

Kalmbacher, R.S., K.R. Long, M.K. Johnson, and F.G. Martin. 1984. Botanical composition of the diets of cattle grazing south Florida rangelands. J. Range Manage. 37:334-340.

Kretschmer, A.E., Jr. 1965. The effect of nitrogen fertilization of mature pangolagrass just prior to utilization in the winter on yields, dry matter, and crude protein contents. Agron. J. 57:529-534.

Kretschmer, A.E., Jr. and G.H. Snyder. 1979. Production and quality of limpograss for use in the subtropics. Agron. J. 71:37-41.

Lewis, C.E. and W.C. McCormick. 1971. Supplementing pine-wiregrass range with improved pasture in south Georgia. J. Range Manage. 24:334-339.

Long, K.R., R.S. Kalmbacher, and F.G. Martin. 1986. Diet quality of steers grazing three-range sites in south Florida. J. Range Manage. 39:389-392.

Medina, E. and N. Motta. 1990. Metabolism and distribution of grasses in tropical flooded savannas in Venezuela. J. Trop. Ecol. 6:77-89.

Moore, J.E. and G.O. Mott. 1974. Recovery of residual organic matter from in vitro digestion of forages. J. Dairy Sci. 57:1258-1259.

Quesenberry, K.H. and W.R.Ocumpaugh. 1980. Crude protein, IVOMD, and yield of stockpiled limpograsses. Agron. J. 72:1021-1024.

Quesenberry, K.H., W.R. Ocumpaugh, O.C. Ruelke, L.S. Dunavin, and P. Mislevy. 1984. Floralta- a limpograss selected for yield and persistence in pastures. Fla. Agr. Exp. Sta. Cir. S-312.

Rechcigl, J.E., P. Mislevy, and A.K. Alva. 1993. Influence of limestone and phosphogypsum on bahiagrass growth and development. Soil Sci. Soc. Amer. 57:96-102.

Ruelke, O.C. and K.H. Quesenberry. 1983. Effects of fertilization timing on the yields, seasonal distribution and quality of limpograss forage. Soil Crops Sci. Soc. Fla. Proc. 42:132-136.

SAS Institute, Inc. 1985. SAS/STAT guide for personal computers. Version 6. SAS Institute, Inc. Cary, N.C.

Schank, S.C., M.A. Klock, and J.E. Moore. 1973. Laboratory evaluation of quality in subtropical grasses. II Genetic variation among Hemarthrias in in vitro digestion and stem-morphology. Agron. J. $65: 256-258$.
Snyder, G.H. and A.E. Kretschmer, Jr. 1986. Effect of K fertilization on growth and recovery of four tropical pasture grasses on a south Florida Spodosol. Soil Crop Sci. Soc. Fla. Proc. 45:75-80.

Tejos, M.R. 1980. Production of water straw grass (Hymenachne amplexicaulis (Rudge) Nees) during a savanna period. Congreso Venezolano de Zootecnia, Guanare (Venezuela) p.54.

Wildin, J.H. 1988. Register of Australian Herbage Plant Cultivars. Tropical Grassl. 22:190.

Wildin, J.H. and D.G. Chapman. 1988. Ponded pasture systems-capitalising on available water. Qucensland Dept. of Primary Industry, Rockhampton, Bull. RQR 87006. 